\title{
Closure of a duodenal cutaneous fistula with endoscopic negative pressure therapy using a thin open-pore film drain - an easy tool and simple method
}

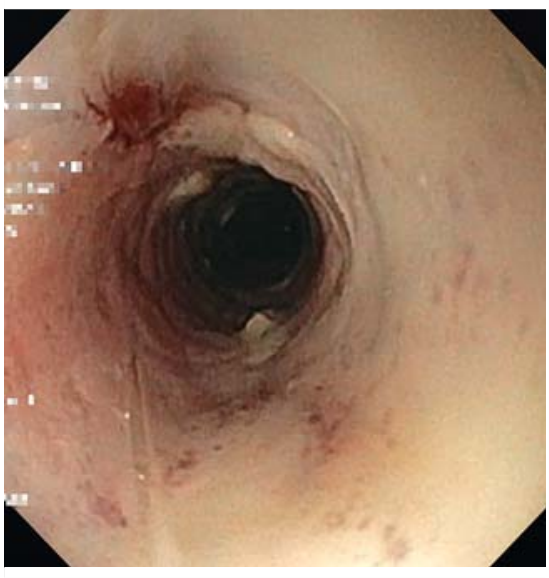

- Fig. 1 Endoscopic view of the long fistula channel after passive drainage with an operative drain.

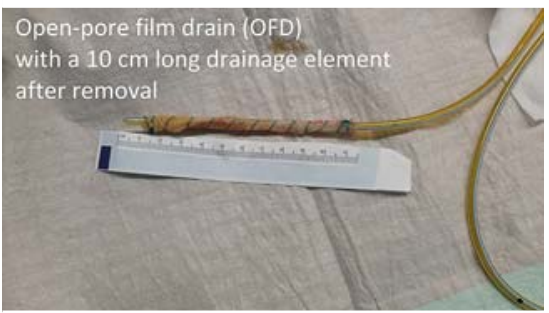

Fig. 3 Removed open-pore film drain after 4 days of negative pressure treatment in the fistula channel.

A 57-year-old patient underwent emergency laparotomy for an acute abdomen with free intra-abdominal air caused by a perforated distal gastric ulcer. Surgical closure was performed by suture. Histological adenocarcinoma was found Therefore, revision laparotomy with distal gastric resection and Roux-en-y reconstruction was done 3 days later. At 6 days postoperatively, a discharge of biliary secretions via target drainage for duodenal stump insufficiency was seen. Surgical closure was tried in another revision laparotomy. But again biliary secretion occurred proving the persistent duodenal leakage.

Passive drainage via the operative drain was sufficient to avoid development of
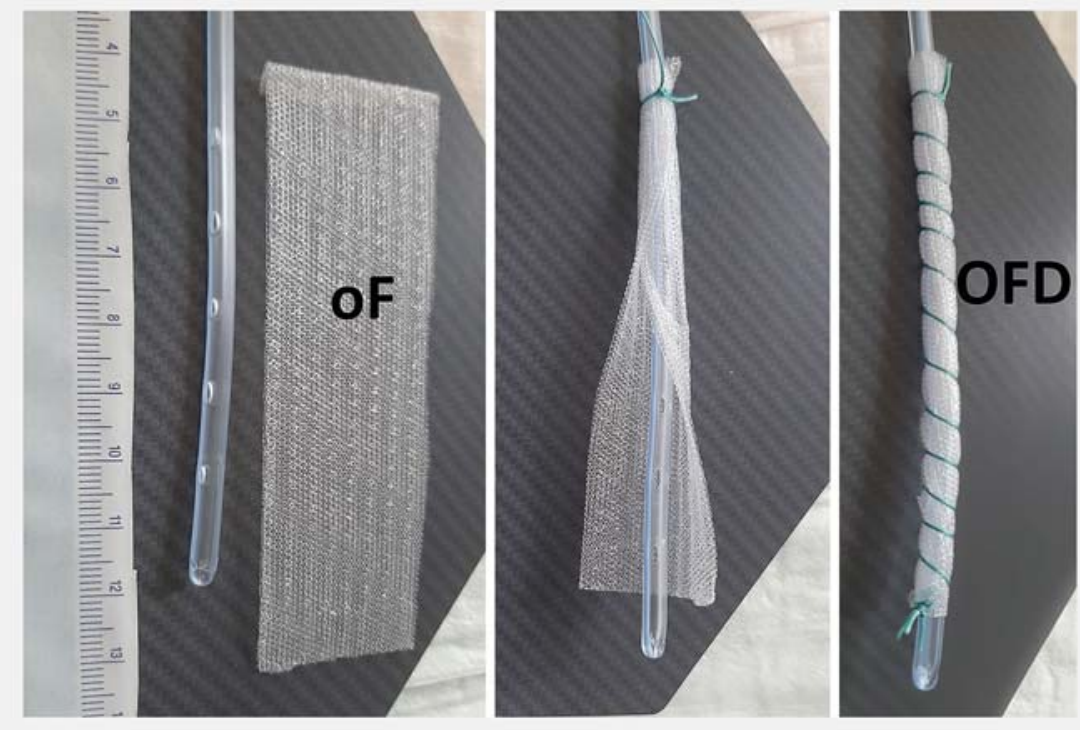

Fig. 2 Making an open-pore film drain: a strip of the double-layered open-pore film is wrapped around the distal end of a small drain tube and fixed with a suture.

an acute abdomen, therefore the duodenal secretions were drained passively. Secretion of $100-200 \mathrm{ml}$ daily persisted for 21 days with formation of a duodenal cutaneous fistula channel ( $>$ Fig. 1 ).

Then, treatment was switched to active drainage management with endoscopic negative pressure using an open-pore film drain. The drain was made by wrapping a strip of thin, double-layered, open-pore film (Suprasorb CNP Drainage Film; Lohmann \& Rauscher, Rengsdorf, Germany) around the distal drainage end and fixing it with a suture [1-5] (ฉ Fig. 2). This created a small-bore open-pore drainage tube to which negative pressure could be applied. The open-pore film drain used had a diameter of only $5 \mathrm{~mm}$. The length of the drainage element was $10 \mathrm{~cm}$. The drain was simply manually inserted in the cutaneous opening into the pre-existing 12-cm-long fistula channel. Suction of $-125 \mathrm{mmHg}$ was applied (ACTIV.A.C; $\mathrm{KCl}$, San Antonio, Texas, USA). The secretion stopped immedi- ately. After 4 days, endoscopic negative pressure treatment was terminated. The open-pore film drain was removed by pulling out the tube ( $>$ Fig.3). Endoscopic inspection of the fistula channel showed the typical suction effects ( Fig.4), with the regular pore structure of the open-pore membrane ( $\triangleright$ Video 1 ). The fistula was closed. The open-pore film drain is a simple device that can be used to achieve duodenal cutaneous fistula closure very easily by negative pressure in appropriate cases.

Endoscopy_UCTN_Code_TTT_1AO_2AI

\section{Acknowledgement}

We would like to thank the nursing staff of the interdisciplinary endoscopic unit of Marienkrankenhaus Hamburg for their excellent technical assistance. 


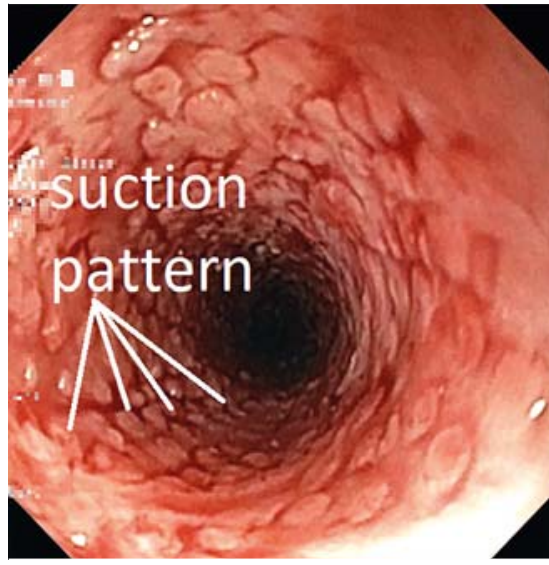

-Fig. 4 Endoscopic view of the fistula channel after 4 days of negative pressure therapy with an open-pore film drain. Typical regular suction pattern can be seen. The tissue of the fistula channel was sucked into the pores of the open-pore film.

\section{Competing interests}

Gunnar Loske is a consultant of Lohmann \& Rauscher GmbH Co. KG.

The authors

Gunnar Loske $९$ Johannes Müller, Anja Röske, Dalia Majert, Wolfgang Schulze, Christian

\section{Theodor Mueller}

Department for General, Abdominal, Thoracic and Vascular Surgery, Katholisches

Marienkrankenhaus Hamburg gGmbH,

Hamburg, Germany

\section{Corresponding author}

\section{Gunnar Loske, MD}

Katholisches Marienkrankenhaus Hamburg gGmbH, Department for General,

Abdominal, Thoracic and Vascular Surgery, Alfredstrasse 9, 22087 Hamburg, Germany Fax: +49-40-2546-1400

loske.chir@marienkrankenhaus.org

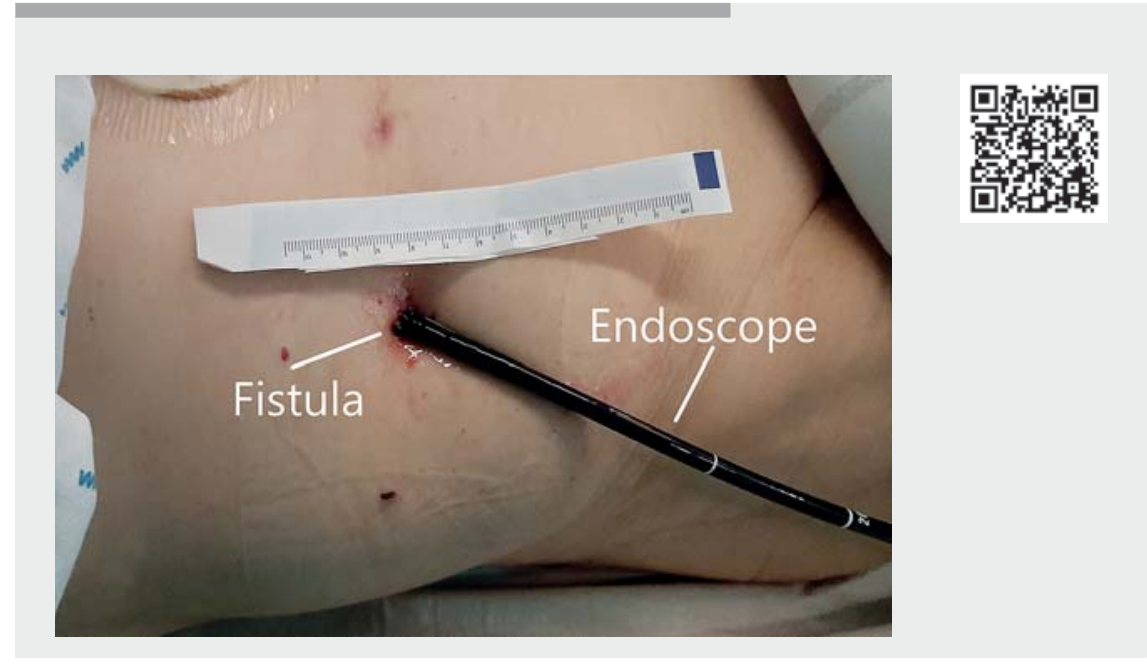

$\checkmark$ Video 1 This video illustrates the course of therapy with the endoscopic aspects of wound healing under negative pressure therapy for fistula closure, creation of the openpore film drain, and removal maneuver.

References

[1] Loske G, Schorsch T, Rucktaeschel F et al. Open-pore film drainage (OFD): a new multipurpose tool for endoscopic negative pressure therapy (ENPT). Endosc Int Open 2018; 6: E865-E871

[2] Loske G, Schorsch T, Gobrecht O et al. Transgastric endoscopic vacuum therapy with a new open-pore film drainage device in a case of infective pancreatic necrosis. Endoscopy 2016; 48: E148-E149

[3] Loske G, Rucktaeschel F, Schorsch T et al. Endoscopic negative pressure therapy (ENPT) for duodenal leakage - novel repair technique using open-pore film (OFD) and polyurethane-foam drainages (OPD). Endosc Int Open 2019; 7: E1424-E1431

[4] Loske G, Müller CT. Tips and tricks for endoscopic negative pressure therapy. Chirurg 2019; 90: 7-14

[5] Müller ], Müller C, Loske G. Getunnelte subkutane endoskopische Unterdrucktherapie. Coloproctology 2021; 43: 46-50
Bibliography

Endoscopy 2022; 54: E490-E491

DOI 10.1055/a-1638-8725

ISSN 0013-726X

published online 8.10 .2021

(c) 2021. Thieme. All rights reserved.

Georg Thieme Verlag KG, Rüdigerstraße 14,

70469 Stuttgart, Germany

\section{ENDOSCOPY E-VIDEOS}

https:/|eref.thieme.de/e-videos

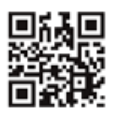

Endoscopy E-Videos is an open access online section, reporting on interesting cases and new techniques in gastroenterological endoscopy. All papers include a high quality video and all contributions are freely accessible online. Processing charges apply (currently EUR 375), discounts and wavers acc. to HINARI are available.

This section has its own submission website at

https://mc.manuscriptcentral.com/e-videos 